\section{PERTANGGUNGJAWABAN BANK TERHADAP HAK NASABAH YANG DIRUGIKAN DALAM PEMBOBOLAN REKENING NASABAH ${ }^{1}$ \\ Oleh : Joice Irma Runtu Thomas ${ }^{2}$}

\begin{abstract}
ABSTRAK
Keberadaan bank dalam kehidupan dewasa ini, mempunyai peran yang cukup penting, mengapa? Karena, lembaga keuangan perbankan khususnya bank umum, merupakan intisari dari sistem keuangan setiap Negara. Sebagai lembaga keuangan, bank yang merupakan tempat masyarakat menyimpan dananya dilandasi oleh kepercayaan bahwa uangnya akan dapat diperoleh kembali pada waktunya dan disertai dengan bunga. Di sini bahwa suatu bank sangat tergantung pada kepercayaan masyarakat tersebut. Namun dari semua itu yang terpenting adalah bagaimana usaha perbankan nasional melaksanakan komitmennya secara konsisten, profesional dan transparan. Hal ini merupakan persyaratan yang mutlak untuk membangun kembali kepercayaan terhadap dunia perbankan nasional.

Kata kunci : Hak Nasabah
\end{abstract}

\section{A. PENDAHULUAN}

Keberadaan bank dalam kehidupan dewasa ini, mempunyai peran yang cukup penting, mengapa? Karena, lembaga keuangan perbankan khususnya bank umum, merupakan inti sari dari sistem keuangan setiap Negara. Bank merupakan lembaga keuangan yang menjadi tempat bagi perusahaan, lembaga pemerintah, swasta maupun perorangan penyimpan dananya, melalui kegiatan perkreditan dan

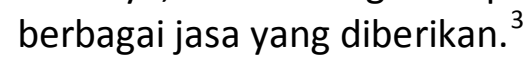

\footnotetext{
${ }^{1}$ Artikel Skripsi

${ }^{2}$ NIM 090711008

${ }^{3}$ Sentosa Sembiring, Hukum Perbankan, CV Mandar Maju, Bandung, 2008, hal 7.
}

Hadirnya dunia usaha sangat diharapkan untuk dapat turut berpartisipasi secara langsung dalam mengembangkan perekonomian nasional, agar dapat mencapai tujuan nasional. Sebagaimana diketahui untuk dapat mewujudkan masyarakat adil dan makmur baik dari seg materil maupun spiritual yang berdasarkan Pancasila dan Undang-undang Dasar 1945, diperlukan adanya pertumbuhan perekonomian yang sangat baik.

Oleh karena itu dukungan dari berbagai bidang sangatlah diperlukan salah satunya adalah di bidang perbankan, karena fungsi utama perbankan adalah menghimpun dana dari masyarakat, dengan harapan dapat memperbaiki tingkat kehidupan ekonomi rakyat banyak ke arah tingkat kehidupan ekonomi yang lebih baik. Namun demikian pelaksanaan pembangunan ekonomi harus tetap memperhatikan dan menjaga stabilitas.

Keberadaan perbankan di Indonesia semakin banyak, hal itu ditandai dengan hadirnya bank-bank baru tumbuh dan berkembang, dana yang berhasil dihimpun dari masyarakat pun merupakan catatan keberhasilan perbankan. Jumlah dana yang dapat dihimpun oleh suatu bank merupakan pencerminan dari meningkatnya kepercayaan masyarakat terhadap bank.

Semakin banyak dana yang dihimpun berarti merupakan suatu indikasi bagi bank, bahwa bank yang bersangkutan mendapat kepercayaan dari masyarakat. Bisnis perbankan merupakan bisnis kepercayaan, oleh karena itu pengelolaan yang hati-hati sangat diperlukan karena dana dari masyarakat dipercayakan kepadanya.

Bank dalam melakukan kegiatan usahanya wajib menerapkan prinsip kehatihatian, dan juga harus menjaga kesehatan bank agar tetap terjaga terus demi kepentingan masyarakat pada umumnya dan bagi para nasabah penyimpan dana. 
Sebagai lembaga keuangan, bank yang merupakan tempat masyarakat menyimpan dananya dilandasi oleh kepercayaan bahwa uangnya akan dapat diperoleh kembali pada waktunya dan disertai dengan bunga, yang dimaksud di sini bahwa suatu bank sangat tergantung pada kepercayaan masyarakat tersebut.

Semakin tinggi kepercayaan masyarakat, semakin tinggi pula kesadaran masyarakat untuk menyimpan uangnya pada bank dan menggunakan jasa-jasa lain dari bank. Bank-bank dalam memberikan produkproduk yang diunggulkan dan berusaha semaksimal mungkin untuk menarik simpati masyarakat.

Seharusnya pihak bank dan pihak nasabah harus berhati-hati dalam mengelola maupun mempercayakan dananya pada bank, karena pihak bank harus bisa mengukur kemampuan untuk membayar kembali dana simpanan nasabah tersebut berikut bunganya.

Sedangkan bagi para nasabah harus memahami benar bank yang bagaimana yang dapat dipercaya, nasabah jangan hanya tergiur oleh bunga yang tinggi maupun bonus atau hadiah dan lainnya, jika ternyata bank yang dipercaya tersebut memiliki kondisi yang kurang baik.

Di Indonesia Lembaga keuangan memiliki misi dan fungsi khusus selain fungsi yang lazim. Bank dituntut untuk berperan sebagai agen pembangunan yaitu sebagai lembaga yang bertujuan mendukung pelaksanaan pembangunan dan hasil-hasilnya, pertumbuhan ekonomi dan stabilitas nasional kearah peningkatan taraf hidup rakyat banyak. ${ }^{4}$

Namun dari semua itu yang terpenting adalah bagaimana usaha perbankan nasional melaksanakan komitmennya secara konsisten, profesional dan transparan. Hal ini merupakan persyaratan

\footnotetext{
${ }^{4}$ H. Budi Untung, Kredit Perbankan di Indonesia, ANDI, Yogyakarta, 2005, hal 14.
}

yang mutlak untuk membangun kembali kepercayaan terhadap dunia perbankan nasional.

Bank Indonesia selaku bank sentral dituntut untuk cermat terhadap kondisi kesehatan bank-bank yang ada di Indonesia, karena jika kondisi suatu bank mengalami kesulitan yang dapat membahayakan kelangsungan usaha dunia perbankan.

Maka bank Indonesia dapat melakukan tindakan agar pemegang saham menambah modal, mengganti dewan komisaris dan direksi bank juga menghapus kredit dan memperhitungkan kerugian bank dengan modalnya, merger atau konsolidasi dengan bank lain yang bersedia mengambil alih beserta seluruh kewajibannya.

Langkah-langkah seperti yang disebutkan di atas dilakukan untuk mempertahankan atau menyelamatkan bank sebagai lembaga kepercayaan masyarakat. Dengan adanya bank-bank yang sakit membuat pemerintah akhirnya mengambil suatu kebijaksanaan untuk melikuidasi bank-bank yang sakit tersebut, karena bank-bank yang sakit tersebut dapat dikhawatirkan akan membahayakan perekonomian bangsa.

Kebijaksanaan pemerintah untuk melikuidasi bank tersebut tentunya akan mempengaruhi peredaran uang dan itu dapat merugikan masyarakat, khususnya nasabah penyimpan dana. Kerugian tersebut ditanggung oleh bank yang bersangkutan, yang akhirnya bisa ditanggung kreditur maupun nasabah.

Banyaknya dana yang dapat dihimpun oleh bank dari masyarakat identik dengan banyaknya nasabah bank, maksudnya bahwa semakin banyak bank yang dapat menarik nasabah, maka bank akan mendapat dana yang semakin besar pula. Oleh karena itu banyak masyarakat menjadi nasabah bank, maka perlu adanya perlindungan hukum bagi nasabah penyimpan dana. 
Fungsi lembaga perbankan sebagai perantara pihak-pihak yang memiliki kelebihan dana dengan pihak-pihak yang memerlukan dana membawa konsekuensi pada timbulnya interaksi yang intensif antara bank sebagai pelaku usaha dengan nasabah sebagai konsumen pengguna jasa perbankan.

Dari sisi pihak yang memiliki kelebihan dana, interaksi dengan bank terjadi pada saat pihak yang kelebihan dana tersebut menyimpan dananya pada bank dalam bentuk giro, tabungan, deposito, sementara dari sisi pihak yang memerlukan dana interaksi terjadi pada saat pihak yang memerlukan dana tersebut meminjam dana dari bank guna keperluan tertentu.

Interaksi antara bank dengan konsumen pengguna jasa perbankan (selanjutnya disebut dengan nasabah) dapat pula mengambil bentuk lain pada saat nasabah melakukan transaksi jasa perbankan selain penyimpanan dan peminjaman dana. Bentuk transaksi lain tersebut seperti misalnya jasa transfer dana, inkaso, maupun safe deposit. ${ }^{5}$

Dalam perkembangannya, nasabah pun dapat memanfaatkan jasa bank untuk mendapatkan produk lembaga keuangan bukan bank, seperti produk asuransi yang dikaitkan dengan produk bank ( bancassurance ) dan reksadana.

Dalam interaksi yang demikian intensif antara bank dengan nasabah di atas, bukan suatu hal yang tidak mungkin apabila terjadi friksi yang apabila tidak segera diselesaikan dapat berubah menjadi sengketa antara nasabah dengan bank.

Dari berbagai pengalaman yang ada, timbulnya friksi tersebut terutama disebabkan oleh empat hal yaitu (i) informasi yang kurang memadai mengenai

\footnotetext{
5 Muliaman D. Hadad, PERLINDUNGAN dan PEMBERDAYAAN NASABAH BANK DALAM ARSITEKTUR PERBANKAN INDONESIA, http://www.google.com, hal 1.
}

karakteristik produk atau jasa yang ditawarkan bank, (ii) pemahaman nasabah terhadap aktivitas dan produk atau jasa perbankan yang masih kurang, (iii) ketimpangan hubungan antara nasabah dengan bank, khususnya bagi nasabah peminjam dana, dan (iv) tidak adanya saluran yang memadai untuk memfasilitasi penyelesaian awal friksi yang terjadi antara nasabah dengan bank.

Untuk menyikapi permasalahan tersebut, maka Bank Indonesia sebagai otoritas pengawas industri perbankan berkepentingan untuk meningkatkan perlindungan terhadap kepentingan nasabah dalam berhubungan dengan bank.

Dengan demikian bank di Indonesia ditugaskan oleh pemerintah untuk turut melaksankan program pemerintah guna mengembangkan sektor-sektor perekonomian tertentu, atau memberikan perhatian yang lebih besar pada koperasi dan pengusaha golongan ekonomi lemah. ${ }^{6}$

Bank yang dengan fungsinya antara lain sebagai perantara pihak-pihak yang mempunyai kelebihan dana ( surplus of fund ) dengan pihak-pihak yang kekurangan dan memerlukan dana ( lock of funds )serta melayani kebutuhan pembiayaan serta melancarkan mekanisme sistem pembayaran bagi semua sektor

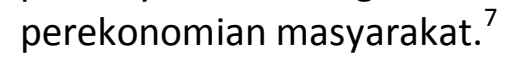

Dengan kondisi demikian, maka bank adalah lembaga yang mengandalkan kepercayaan masyarakat. Guna mengekalkan kepercayaan masyarakat terhadap bank pemerintah harus berusaha melindungi masyarakat dari tindakan lembaga ataupun oknum pegawai bank yang tidak bertanggungjawab dan merusak sendi kepercayaan masyarakat.

\footnotetext{
${ }^{6}$ Op-Cit, H. Budi Untung, hal 14.

7 Muhamad Djumhana, Hukum Perbankan di Indonesia, PT Citra Aditya Bakti, Bandung, 2006, hal 337.
} 
Pada prinsipnya hubungan antara bank dan nasabah penyimpan dananya dilandasi hubungan kepercayaan, yang lazimnya disebut fiduciary relation. Bank terutama bekerja dengan dana dari masyarakat yang disimpan padanya atas dasar kepercayaan, sehingga setiap bank perlu terus menjaga kesehatannya dengan tetap memelihara dan mempertahankan kepercayaan masyarakat padanya. ${ }^{8}$

Kemauan masyarakat untuk menyimpan sebagian uangnya di bank, semata-mata dilandasi oleh kepercayaan bahwa uangnya akan dapat diperolehnya kembali pada waktu yang diinginkan yang disertai dengan imbalan pula. Apabila kepercayaan nasabah penyimpan dana terhadap suatu bank telah berkurang, tidak tertutup kemungkinan akan terjadi rush terhadap dana yang disimpannya.

Ketidakpercayaan pada industri perbankan dapat menjadikan industri tersebut ambruk dalam waktu sekejap. Saat ini Indonesia sedang merasakan betul arti penting kepercayaan pada dunia perbankan: sebuah pelajaran yang harus dibayar dengan mahal.

Sesungguhnya hubungan antara bank dan nasabah penyimpan dana bukan sekedar hubungan kontraktual biasa antara debitur (bank) dan kreditur (nasabah penyimpan dana) yang diliputi oleh asasasas umum dari hukum perjanjian, tetapi juga hubungan kepercayaan yang diliputi asas kepercayaan.

Pengakuan tersebut membawa konsekuensi bahwa hubungan antara bank tidak boleh hanya memperhatikan kepentingannya sendiri semata-mata, tetapi juga harus memperhatikan kepentingan nasabah penyimpan dana. Berbeda dengan industri lainnya, maka pengaturan industri perbankan lebih banyak dilakukan oleh pemerintah.

${ }^{8}$ Djoni S. Gazali dan Rachmadi Usman, Hukum Perbankan, Sinar Grafika, Jakarta, 2010, hal 556.
Hal ini dilakukan untuk melindungi masyarakat dari perbuatan-perbuatan dan praktek-praktek yang tidak terpuji yang dapat merugikan kepentingan masyarakat luas. Kenyataan menunjukkan di manapun industri perbankan merupakan industri yang paling banyak diatur pemerintah dibandingkan dengan industri-industri lainnya.

Kegiatan perbankan lebih banyak tergantung kepada dana masyarakat sehingga perlu dijamin kepastian keamanannya. Selain itu, penyaluran dana perbankan merupakan bisnis beresiko tinggi, yang apabila tidak dikelolah dengan baik dapat menganggu tidak hanya kelangsungan usaha bank itu sendiri, namun juga sistem perbankan dan kestabilan moneter.

Mengembalikan

kepercayaan masyarakat dan sekaligus melindungi hakhak penyimpan dana, akhirnya pemerintah mengeluarkan Keputusan Presiden Nomor 26 Tahun 1998 tentang Jaminan terhadap Kewajiban pembayaran Bank Umum.

Dan Keputusan Presiden Nomor 1993 Tahun 1998 tentang Program Penjaminan Bank Perkreditan Rakyat, yang pada intinya memberi perlindungan hukum secara langsung kepada nasabah penyimpan dana terhadap kegagalan Bank Umum maupun BPR dalam memenuhi kewajibannya Sebelum dikeluarkan Keputusan Presiden Nomor 26 Tahun 1998, perlindungan terhadap nasabah sangat minim dalam badan hukum perbankan Indonesia.

Perlindungan hukum penting mengingat bank merupakan lembaga keuangan yang dalam pelaksanaannya tidak bisa lepas dari peran para nasabah, karena hubungan hukum nasabah dengan bank merupakan hubungan hukum yang tercipta atas dasar kepercayaan ( fiduciary relation ). ${ }^{9}$

\section{B. PERUMUSAN MASALAH}

\footnotetext{
${ }^{9}$ Ibid, hal 568.
} 
1. Bagaimana pertanggung jawaban bank terhadap hak nasabah yang dirugikan?

2. Bagaimana hak dan kewajiban nasabah serta perlindungan hukumnya?

\section{METODE PENELITIAN}

Metode yang digunakan dalam penulisan skripsi ini adalah metode penelitian kepustakaan ( library Research), yaitu suatu metode penelitian yang digunakan dengan jalan mempelajari bukubuku literatur, peraturan perundang undangan, bahan - bahan tertulis lainnya, majalah-majalah hukum, surat kabar, artikel-artikel dalam situs internet, juga bahan-bahan kuliah yang digunakan dalam pembahasan ini guna mendukung materi pokok dalam skripsi ini.

\section{TINJAUAN PUSTAKA}

\section{Pengertian Bank}

Bank adalah salah satu badan usaha lembaga keuangan yang bertujuan memberikan kredit dan pemberian jasajasa. Adapun pemberian kredit itu dilakukan baik dengan modal sendiri atau dengan dana-dana yang dipercayakan oleh pihak ketiga maupun dengan jalan memperedarkan alat-alat pembayaran baru berupa uang giral.

Menurut Undang-undang Nomor 7 Tahun 1992 jo Undang-Undang Nomor 10 Tahun 1998 tentang Perbankan Pasal 1 butir 2, Bank adalah badan usaha yang menghimpun dana dari masyarakat dalam bentuk kredit dan atau bentuk simpanan dan menyalurkannya kepada masyarakat dalam bentuk kredit dan atau bentukbentuk lainnya dalam rangka meningkatkan taraf hidup rakyat banyak.

Bank merupakan lembaga keuangan yang menjadi tempat bagi perusahaan, badan-badan pemerintah dan swasta, maupun perorangan untuk menyimpan dana-dananya.

Menurut Prof. G. M. Verryn Stuart di dalam bukunya Bank Politik mengatakan bahwa bank adalah suatu badan yang bertujuan untuk memuaskan kebutuhan kredit, baik dengan alat-alat pembayaran sendiri, dengan uang yang diperolehnya dari orang lain, maupun dengan jalan memperedarkan alat-alat penukar uang berupa uang giral. ${ }^{10}$

Dalam Undang-Undang Nomor 14 Tahun 1967 tentang Pokok Perbankan yang memberikan pengertian Bank sebagai lembaga keuangan yang usaha pokoknya memberikan kredit dan jasa-jasa dalam lalu lintas pembayaran dan peredaran uang.

Menurut Undang-undang Nomor 7 Tahun 1992 tentang Perbankan : Bank adalah badan usaha yang menghimpun dana dari masyarakat dalam bentuk simpanan, dan menyalurkan kepada masyarakat dalam rangka meningkatkan taraf hidup rakyat banyak.

Menurut Undang-undang Nomor 10 Tahun 1998 Perubahan Undang-undang Nomor 7 Tahun 1992 tentang Perbankan : Bank adalah badan usaha yang menghimpun dana dari masyarakat dalam bentuk simpanan dan menyalurkannya kepada masyarakat dalam bentuk kredit dan atau bentuk-bentuk lainnya dalam rangka meningkatkan taraf hidup rakyat banyak.

Menurut Kasmir dalam bukunya Manajemen Perbankan, secara sederhana bank dapat diartikan sebagai "lembaga keuangan yang kegiatan utamanya adalah menghimpun dana dari masyarakat dan menyalurkan kembali dana tersebut ke masyarakat serta memberikan jasa bank lainnya".

Menurut. H. Malayu S.p Hasibuan : "Bank adalah lembaga keuangan berarti Bank adalah badan usaha yang kekayaan terutama dalam bentuk asset keuangan (Financial Assets) serta bermotivasi profit

\footnotetext{
${ }^{10}$ O. P. Simorangkir, Pengantar Lembaga Keuangan Bank dan Non Bank, GHALIA Indonesia, 2004, hal 10.
} 
dan juga sosial, jadi bukan mencari keuntungan saja."

Menurut kamus istilah hukum Fockema Andreae, yang dimaksud dengan bank adalah suatu lembaga atau orang pribadi yang menjalankan perusahaan dalam menerima dan memberikan uang dari dan kepada pihak ketiga.

\section{Pengertian Nasabah}

Menurut kamus besar bahasa Indonesia, Nasabah ialah (a) orang yang biasa berhubungan atau menjadi pelanggan bank (dalam hal keuangan); (b) Orang yang menjadi tanggung jawab asuransi; dan (c) perbandingan, pertalian.

Menurut kamus perbankan mendefinisikan nasabah sebagai orang atau badan yang mempunyai rekening simpanan atau pinjaman pada bank. Menurut tim pusat bahasa, nasabah adalah orang yang biasa berhubungan atau menjadi pelanggan bank.

Menurut Wikipedia, Nasabah adalah pihak yang menggunakan jasa bank, baik itu untuk keperluannya sendiri maupun sebagai perantara bagi keperluan pihak lain.

Undang-Undang Nomor 10 Tahun 1998 nasabah adalah pihak yang menggunakan jasa bank. Nasabah ini dibagi atas 2 yaitu :

"Nasabah penyimpan adalah nasabah yang menempatkan dananya di bank dalam bentuk simpaan berdasarkan perjanjian bank dengan nasabah yang bersangkutan.Nasabah Debitur adalah nasabah yang memperoleh fasilitas kredit atau pembiayaan berdasarkan prinsip syariah atau yang dipersamakan dengan nasabah yang bersangkutan." ${ }^{11}$

Dalam Pengaturan Bank Indonesia No $7 / 7 / \mathrm{PBI} / 2005$ jo No $10 / 10 / \mathrm{PBI} / 2008$

\footnotetext{
${ }^{11}$ Lukman Santoso Az, Hak dan Kewajiban Hukum Nasabah Bank, Pustaka Yustisia, 2011, hal 27.
}

tentang penyelesaian Pengaduan Nasabah Pasal 1 angka 2, mendefinisikan nasabah sebagai pihak yang menggunakan jasa bank, termasuk pihak yang tidak memiliki rekening namun memanfaatkan jasa bank untuk melakukan transaksi keuangan ( walk in customer ).

Sedangkan dari praktik-praktik perbankan, setidaknya dikenal tiga macam nasabah. Pertama, nasabah deposan yaitu nasabah yang menyimpan dananya pada suatu bank, misalnya dalam bentuk deposito atau tabungan lainnya. Kedua, yaitu nasabah yang memanfaatkan fasilitas kredit perbankan.

Misalnya kredit usaha kecil, kredit pemilikan rumah dan sebagainya. Dan ketiga, nasabah yang melakukan transaksi dengan pihak lain melalui bank. Misalnya transaksi antara impotir sebagai pembeli dan eksportir di luar negeri. Untuk transaksi semacam ini biasanya importir membuka letter of credit (L/C) pada suatu bank demi kelancaran dan keamanan pembayaran.

Dari pengertian-pegertian diatas dapat disimpulkan bahwa nasabah adalah orang yang menjadi pelanggan bank yang mempunyai rekening simpanan dan pinjaman ataupun tidak. Sehingga nasabah dalam arti luas, juga bisa dipahami sebagai konsumen bank.

\section{Fungsi Bank}

Di Indonesia Lembaga Keuangan bank memiliki misi dan fungsi khusus selain fungsi yang lazim seperti apa yang telah diuraikan di atas. Bank diarahkan untuk berperan sebagai agen pembanguna ( agent of development ), yaitu sebagai lembaga yang bertujuan mendukung pelaksanaan pembangunan nasional dalam rangka meningkatkan pemerataan pembangunan dan hasil-hasilnya, pertumbuhan ekonomi dan stabilitas nasional kearah peningkatan taraf hidup rakyat banyak. 
Fungsi tersebut merupakan penjabaran dari Pasal 4 Undang-Undang Perbankan Tahun 1992, yaitu bahwa perbankan Indonesia bertujuan menunjang pelaskanaan pembangunan nasional dalam rangka meningkatkan pemerataan, pertumbuhan ekonomi, dan stabilitas nasional kearah peningkatan kesejahteraan rakyat banyak.

Dengan demikian Bank di Indonesia ditugaskan oleh pemerintah untuk turut melaksanakan program pemerintah guna mengembangkan sektor-sektor perekonomian tertentu, atau memberikan perhatian yang lebih besar pada koperasi tertentu, atau memberikan perhatian yang lebih besar pada koperasi dan pengusaha golongan ekonomi lemah/pengusaha kecil dalam rangka meningkatkan taraf hidup rakyat banyak.

Hal tersebut menunjukan bahwa perbankan di Indonesia selain memiliki tugas-tugas tradisional, yaitu menghimpun dana dan memberikan kredit, juga dapat berfungsi untuk menjaga kestabilan moneter. ${ }^{12}$

Hal itu terlihat pada saat pengembangan moneter 1987 yang ditandai oleh adanya spekulasi valuta asing yang kemudian bisa diatasi keadaan spekulasi semacam itu. Pada saat-saat di mana stabilitas dipertaruhkan maka selayaknnya perbankan bersama-sama dengan lembaga lainnya dan masyarakat memprioritaskan upaya turut menstabilkan keadaan moneter.

Fungsi perbankan tidak hanya sekadar sebagai wadah penghimpun dan penyalur dana masyarakat atau perantara penabung dan investor, tetapi fungsinya akan diarahkan kepada peningkatan taraf hidup rakyat banyak, agar masyarakat menjadi lebih baik dan sejahtera dari pada sebelumnya. ${ }^{13}$

\footnotetext{
${ }^{12} \mathrm{H}$. Budi Untung, Kredit Perbankan di Indonesia, ANDI, Yogyakarta, 2005, hal 14.

${ }^{13}$ Op-Cit, Lukman Santoso Az, hal 43.
}

Oleh karena itu dalam menjalankan fungsinya, perbankan Indonesia seyogianya selalu mengacu pada tujuan perbankan Indonesia itu sendiri.

\section{E. PEMBAHASAN}

\section{Pertanggung Jawaban Bank Terhadap Hak Nasabah}

Pelanggaran hak nasabah oleh bank dapat diselesaikan melalui jalur hukum. Namun ketika kita kembali sadarkan terhadap nilai-nilai Negara hukum Pancasila dan Undang-Undang Dasar 1945 yang mengedepankan asas musyawarah, forum mediasi merupakan dimensi yang juga penting. ${ }^{14}$

Artinya, ketika sengketa perbankan masih dapat diselesaikan secara baik dan tetap menguntungkan kedua belak pihak, maka jalur hukum atau pengadilan dapat dikesampingkan/dihentikan. Hal ini juga terkait dengan prinsip penyelesaian sengketa secara murah, sederhana dan cepat.

Hadirnya upaya tersebut tentu tidak terlepas dari hubungan timbal balik antara nasabah dan bank, baik itu nasabah penyimpan dalam bentuk tabungan maupun deposito atau nasabah lain. Hubungan timbal balik ini dapat berupa pemberian bunga oleh pihak bank terhadap simpanan dari nasabah, serta kewajibankewajiban nasabah untuk memenuhi ketentuan system administrasi tertentu apabila hendak mengambil atau menyimpan uang.

Selain itu sebagai upaya peningkatan dan pemberdayaan nasabah, tentu bank sebagai pelaku usaha harus memberikan layanan penyelesaian dan infrastruktur atas berbagai keluhan dan pengaduan nasabah. Media penyelesaian ini juga harus memenuhi standar waktu dan pelayanan,

\footnotetext{
${ }^{14}$ Lukman Santoso Az, Hak dan Kewajiban Hukum Nasabah Bank, Yogyakarta, 2011, hal 126.
} 
Artinya dapat berlaku secara efektif dan efesien.

Bank Indonesia sebagai pemegang otoritas perbankan Indonesia dalam upaya memenuhi standar tersebut juga telah memprioritaskan program-program terkait perlindungan nasabah, termasuk penanganan pengaduan nasabah, termasuk penanganan perbankanan pembentukan lembaga mediasi perbankan independen.

Dalam ranah hukum, seorang tentu harus bertanggung jawab terhadap kerugian yang diakibatkan oleh perbuatan yang bertentangan dengan hukum dari orang lain. hal ini disebut tanggungjawab kwalitatif, yaitu orang yang bertanggung jawab karena orang itu memiliki suatu kwalitas tertentu.

Sesuai dengan penerapan hukum di Indonesia, seorang konsumen yang dilakukan oleh pelaku usaha, termasuk nasabah kepada bank, dapat menggugat pihak yang menimbulkan kerugian atas produk dan jasanya tersebut. Kwalifikasi gugatan yang lazim adalah wanprestasi atau perbuatan melawan hukum.

Dalam gugatan adanya wanprestasi, maka terdapat hubungan kontraktual antara konsumen dan pelaku usaha/produsen. Kerugian yang dialami oleh nasabah tidak lain adalah karena tidak dilaksanakan prestasi oleh bank sebagai pelaku usaha.

Apabila tidak terdapat hubungan kontraktual antara nasabah dan bank, maka tidak ada tanggung jawab (hukum) pelaku usaha nasabah. Hal inilah yang dikenal dengan doktrin yang mengandung prinsip "tidak ada hubungan kontraktual, tidak ada tanggung jawab".

Sedangkan dalam gugatan berdasarkan perbuatan melawan hukum, hubungan kontraktual tidaklah disyaratkan. Dalam hal ini nasabah haruslah membuktikan adanya unsur-unsur:

1. Adanya perbuatan melawan hukum,
2. Adanya kesalahan/kelalaian pelaku usaha,

3. Adanya kerugian yang dialami oleh konsumen,

4. Adanya hubungan kausal antara perbuatan melawan hukum dan kerugian yang dialami oleh konsumen.

Pada UUPK, dalam konteks pertanggungjawaban pelaku usaha atas gugatan nasabah ini, diatur beberapa ketentuan :

1. Pertanggung jawaban Pidana Korporasi

Subjek hukum tindak pidana UndangUndang Perlindungan Konsumen adalah pelaku usaha. Pelaku usaha yang termasuk dalam pengertian ini adalah perusahaan, korporasi, BUMN, koperasi, impotir, pedagang, distributor, dan lain-lain. Artinya, bank pemerintah maupun swasta, termasuk Bank Perkreditan termasuk kategori ini.

2. Hak gugat Lembaga Konsumen

Lembaga konsumen, atas nama kepentingan konsumen, dapat mengajukan gugatan atas pelanggaran yang dapat dilakukan pelaku usaha yang merugikan kepentingan konsumen (Pasal 46 ayat (1) huruf c UUPK). Disini lembaga konsumen mempunyai hak gugat ( legal standing to sue ) kepada pelaku usaha, lepas ada atau tidak ada surat kuasa dari konsumen yang dirugikan.

3. Gugatan Kepentingan kelompok

Terhadap sengketa konsumen yang melibatkan konsumen dalam jumlah besar/missal, padahal ini persoalaan menyangkut hal yang sama, konsumen dapat mengajukan gugatan kepentingan kelompok ( class action ) kepada pelaku usaha (Pasal 46 ayat (1) huruf b UUPK).

\section{Beban Pembuktian terbalik}

Pelaku usaha bertanggung jawab memberikan ganti rugi atas kerusakan, pencemaran, dan/atau kerugian konsumen akibat menggunakan produk atau jasa yang dihasilkan atau diperdagangkan (Pasal 19 ayat (1) UUPK). 
Ganti rugi dapat berupa pengembalian uang atau penggantian barang dan/atau jasa yang sejenis atau setara nilainya, atau perawatan kesehatan dan/atau pemberian santunan yang sesuai dengan ketentuan peraturan Perundang-Undangan yang berlaku. $^{15}$

Ketentuan ini tidak berlaku apabila pelaku usaha dapat membuktikan bahwa kerugian tersebut merupakan atau sebagai akibat kesalahan konsumen. Sehingga, pembuktian terhadap ada tidaknya unsur kesalahan dalam gugatan- gugatan ganti rugi, merupakan beban dan tanggung jawab pelaku usaha (Pasal 28 UUPK).

Pada umumnya nasabah akan mengalami kesulitan untuk membuktikan unsur ada tidaknya kesalahan atau kelalaian pelaku usaha. Untuk itulah dianut doktrin productliability, dimana tergugat dianggap telah bermasalah (presumption of guilty) kecuali ia mampu membuktikan bahwa ia tidak melakukan kelalaian atau kesalahan. Maka ia harus memikul resiko kerugian yang dialami pihak lain karena mengkonsumsi atau menggunakan produknya.

Peraturan Bank Indonesia Nomor 5/8/PBI/2003 tentang Penerapan Manajemen Risiko Bagi Bank Umum (selanjutnya disingkat PBI No. 5/8/ $\mathrm{PBI} / 2003)$. Perlunya manajemen resiko ini ada kaitannya dengan kepercayaan masyarakat terhadap dunia perbankan, sehingga perlu menghindari potensi terjadinya suatu peristiwa ( events ) yang dapat menimbulkan kerugian bank. ${ }^{16}$

Sedangkan mengenai manajemen resiko merupakan serangkaian prosedur dan metodologi yang digunakan untuk mengidentifikasi, mengukur, memantau, dan mengendalikan resiko yang timbul dari kegiatan usaha bank. Perihal manajemen

\footnotetext{
${ }^{15}$ Ibid, hal 128.

${ }^{16}$ Muhammad Djumhana, Hukum Perbankan Di Indonesia, Citra Aditya Bakti, Bandung, 2000, h. 370371.
}

resiko, bank wajib menerapkan Manajemen Resiko secara efektif.

Penerapan Manajemen Resiko sebagaimana dimaksud dalam ayat (1) sekurang-kurangnya mencakup:

a. pengawasan aktif dewan Komisaris dan Direksi;

b. kecukupan kebijakan, prosedur, dan penetapan limit;

c. kecukupan proses identifikasi, pengukuran, pemantauan dan pengendalian resiko serta sistem informasi Manajemen Resiko; dan

d. sistem pengendalian intern yang menyeluruh sebagaimana pasal $2 \mathrm{PBI}$ No. 5/8/PBI/2003.

Resiko perbankan tersebut menurut Pasal 4 PBI No. 5/8/PBI/2003 meliputi:

(1) Resiko sebagaimana dimaksud dalam Pasal 2 mencakup:
a. Risiko Kredit;
b. Resiko Pasar;
c. Risiko Likuiditas;
d. Resiko Operasional;
e. Resiko Hukum;
f. Resiko Reputasi;
g. Resiko Strategik;
h. Resiko Kepatuhan.

(2) Bank yang memiliki ukuran dan kompleksitas usaha yang tinggi wajib menerapkan Manajemen Resiko sebagaimana dimaksud dalam Pasal 2 ayat (2) untuk seluruh jenis risiko sebagaimana dimaksud dalam ayat (1).

Mengenai pihak yang berwenang dan bertanggung jawab atas resiko yang terjadi adalah komisaris dan direksi. Menurut Pasal 6 PBI No. 5/8/PBI/2003 menentukan sebagai berikut:

Wewenang dan tanggung jawab bagi dewan Komisaris sekurangkurangnya:

a. menyetujui dan mengevaluasi kebijakan Manajemen Resiko;

b. mengevaluasi pertanggungjawaban Direksi atas pelaksanaan kebijakan 
Manajemen Resiko sebagaimana dimaksud dalam huruf a;

c. mengevaluasi dan memutuskan permohonan Direksi yang berkaitan dengan transaksi yang memerlukan persetujuan dewan Komisaris.

Sedangkan kewenangan dan

Tanggung Jawab Direksi diatur dalam Pasal 7 PBI No. 5/8/PBI/2003 yang menentukan:

(1) Wewenang dan tanggung jawab sebagaimana dimaksud dalam Pasal 5 bagi Direksi sekurang-kurangnya:

a. menyusun kebijakan dan strategi Manajemen Resiko secara tertulis dan komprehensif;

b. bertanggung jawab atas pelaksanaan kebijakan Manajemen Resiko dan eksposur Resiko yang diambil oleh Bank secara keseluruhan;

c. mengevaluasi dan memutuskan transaksi yang memerlukan persetujuan Direksi;

d. mengembangkan budaya Manajemen Resiko pada seluruh jenjang organisasi;

e. memastikan peningkatan kompetensi sumberdaya manusia yang terkait dengan Manajemen Resiko;

f. memastikan bahwa fungsi Manajemen Resiko telah beroperasi secara independen;

g. melaksanakan kaji ulang secara berkala untuk memastikan:

1. keakuratan metodologi penilaian Resiko;

2. kecukupan implementasi sistem informasi manajemen; dan

3. ketepatan kebijakan, prosedur dan penetapan limit Resiko.

(2) Dalam rangka melaksanakan wewenang dan tanggung jawab sebagaimana dimaksud dalam ayat (1), Direksi harus memiliki pemahaman yang memadai mengenai Resiko yang melekat pada seluruh aktivitas fungsional Bank dan mampu mengambil tindakan yang diperlukan sesuai dengan profil Resiko. ${ }^{17}$

\section{Hak Dan Kewajiban Nasabah Serta Perlindungan Hukumnya}

Kepentingan konsumen, termasuk pula dalam hal ini nasabah, secara rinci termuat dalam Revolusi PBB Nomor 39/248 Tahun 1985. Dalam sidang umum PBB ke-106 yang digelar tanggal 9April 1985 itu, digariskan bahwa hak-hak konsumen yang dimaksud yaitu :

1. Perlindungan terhadap konsumen dari bahaya-bahaya terhadap kesehatan dan keamanannya.

2. Promosi dan perlindungan dari kepentingan sosial ekonomi konsumen.

3. Tersedianya informasi yang memadai bagi konsumen untuk memberikan mereka kemampuan melakukan pilihan yang tepat sesuai dengan kehendak dan kebutuhan pribadi.

4. Pendidikan konsumen.

5. Tersedianya upaya ganti rugi yang efektif.

6. Kebebasan untuk membentuk organisasi konsumen dan memberikannya kesempatan kepada mereka untuk menyatakan pendapat sejak saat proses pengambilan keputusan yang berhubungan dengan kepentingan konsumen.

Dalam Pasal 4 Bab III Undang-Undang Nomor 8 Tahun 1999 tentang Perlindungan Konsumen, menyebutkan hak-hak konsumen secara khusus, yaitu antara lain :

1. hak atas kenyamanan, keamanan, dan keselamatan dalam mengkonsumsi barang dan/atau jasa;

2. hak untuk memilih barang dan/atau jasa serta mendapatkan barang dan/atau jasa tersebut sesuai dengan nilai tukar dan kondisi serta jaminan yang dijanjikan;

3. hak atas informasi yang benar, jelas, dan jujur mengenai kondisi dan jaminan barang dan/atau jasa;

\footnotetext{
${ }^{17}$ Ibid, hal 371.
} 
4. hak untuk didengar pendapat dan keluhannya atas barang dan/atau jasa yang digunakan;

5. hak untuk mendapatkan advokasi, perlindungan, dan upaya penyelesaian sengketa perlindungan konsumen secara patut;

6. hak untuk mendapat pembinaan dan pendidikan konsumen;

7. hak untuk diperlakukan atau dilayani secara benar dan jujur serta tidak diskriminatif;

8. hak untuk mendapatkan kompensasi, ganti rugi dan/atau penggantian, apabila barang dan/atau jasa yang diterima tidak sesuai dengan perjanjian atau tidak sebagaimana mestinya;

9. hak-hak yang diatur dalam ketentuan peraturan perundang-undangan lainnya.

Secara spesifik, hak-hak konsumen, terutama kepentingan hukumnya, telah termuat dalam Undang-Undang Nomor 8 Tahun 1999, dalam hal itu merupakan kepentingan yang mutlak dan sah bagi masyarakat Indonesia sebagai konsumen.

Suatu hal yang tidak adil bagi konsumen bila kepentingan konsumen tidak seimbang dan tidak dihargai sebagaimana penghargaan terhadap kalangan pengusaha. Dalam konteks itu, nasabah memiliki hak secara spesifik, yakni sebagai berikut :

1. Nasabah berhak untuk mengetahui secara terperinci tentang produkproduk perbankan yang ditawarkan.

Hak ini merupakan hak utama dari nasabah, karena tanpa penjelasan terperinci dari bank melalui customer service-nya, maka sangat sulit nasabah untuk memilih produk perbankan apa yang sesuai dengan kehendaknya. Hak-hak apa saja yang akan diterima oleh nasabah apabila nasabah mau menyerahkan dananya kepada bank untuk dikelola.
2. Nasabah berhak untuk mendapatkan bunga atas produk tabungan dan deposito yang telah diperjanjikan terlebih dahulu.

Dalam praktik perbankan berlaku ketentuan bahwa nasabah yang akan menyimpan dananya pada waktu suatu bank dilakukan bukan dengan cuma-cuma. Nasabah berhak untuk menerima bunga atas dana yang disimpan pada bank tersebut.

Besarnya bunga ini dapat dilihat pada ketentuan yang berlaku pada setiap bank menurut produk perbankan yang ada. Bagi bank berdasarkan prinsip syariah nasabah penyimpan dana berhak atas bagian keuntungan dana yang disimpan.

Sedangkan kewajiban nasabah, diatur dalam pasal 5 Undang-Undang Nomor 8 Tahun 1999, yang menyatakan bahwa kewajiban konsumen, yaitu :

1. Membaca atau mengikuti petunjuk informasi dan prosedur pemakaian atau pemanfaatan barang dan/atau jasa, demi keamanan dan keselamatan;

2. beretikad baik dalam melakukan transaksi pembelian barang dan/atau jasa;

3. membayar sesuai dengan nilai tukar yang disepakati;

4. mengikuti upaya penyelesaian hukum sengketa perlindungan konsumen secara patuh.

Kewajiban nasabah dalam hubungannya dengan bank, pada umumnya harus memerhatikan wujud bank tersebut dengan mewakilkan pemantauan dan analisis terhadap indikator-indikator penting yang bisa mendeteksi gejala dari kemungkinan timbulnya masalah pada bank tersebut.

Adapun hal-hal yang harus diperhatikan oleh seorang nasabah dalam hubungannya dengan sebuah bank adalah sebagai berikut

a. Menilai kewajaran terhadap tingkat suku bunga produk tabungan dan deposito, yang dikaitkan dengan 
tingkat suku bunga pasar yang umumnya berlaku.

Apabila tingkat suku bunga tinggi produk tabungan dan deposito terlalu tinggi bila dibandingkan dengan tingkat suku bunga pasar pada umumnya, maka semakin besar resiko yang harus dipikul oleh seorang nasabah.

b. Nasabah harus menilai akan kemampuan bank tersebut dalam mencetak laba setelah kena pajak selama 2 tahun berturut-turut. Laba tersebut harus merupakan laba yang didapat dalam pendapat bank, bukan dari penjualan aktiva bank tersebut.

c. Nasabah juga harus memerhatikan ekspansi kredit yang dilakukan bank tersebut, juga harus dengan net interest margin (selisih antara pendapatan dan biaya bunga). Artinya bila ekspansi kreditnya tinggi dan NIMnya rendah, berarti bank tersebut dalam kondisi yang tidak baik, begitu sebaliknya.

d. Nasabah juga harus memerhatikan loan deposit ratio (perbandingan antara peminjam yang diberikan sebelum dikurangi perselisihan piutang ragu-ragu dan sumber dana pihak ketiga). LDR yang baik sesuai dengan ketentuan Bank Indonesia, yakni antara $70-80 \%$. Bila LDR-nya lebih dari $110 \%$ berarti bank tersebut kurang baik.

e. Lihat pula apakah dana pihak ketiga yang ditempatkan oleh bank tersebut ditempatkan dalam aktiva produktif.

f. Perhatikan juga rasio antara modal bank tersebut dan asset bank.

Perlindungan bagi para nasabah penyimpan dana memang merupakan suatu hal yang bersifat mutlak bagi para pelaku bisnis perbankan. Selama ini, kurang terlindunginya para nasabah penyimpan saat ini memang dapat dirasakan sejak pertama kali nasabah penyimpan menyerahkan dana mereka pada bank yang dipercayai tersebut.
Secara yuridis, hubungan antara bank dengan nasabah penyimpan adalah berkaitan satu sama lain, disatu pihak nasabah menginginkan dana yang dimilikinya aman dengan dititipkan pada bank, disisi yang lain bank mengharapkan masyarakat menitipkan dananya pada bank yang bersangkutan dengan harapan dana yang terkumpul nantinya dapat disalurkan melalui kredit dan bank memperoleh imbalan bunga dari pihak debitur.

Dalam rangka pembukaan rekening simpanan, para nasabah tidak cukup mendapat informasi yang memadai mengenai keamanan atas dana yang mereka akan titipkan pada bank, tetapi bank hanya memberikan informasi tentang tingkat suku bunga, biaya administrasi, jangka waktu simpanan (khusus deposito) dan cara penarikan dana kembali serta saldo minimal yang boleh tersisa.

Ketidak berimbangan posisi hukum antara nasabah penyimpan dana dengan bank merupakan faktor utama dimunculkannya mengenai perlindungan dana nasabah penyimpan dana berdasarkan Undang-undang Republik Indonesia No.24 Tahun 2004 tentang Lembaga Penjamin Simpanan (LPS).

Dengan demikian, diharapkan nantinya setiap nasabah mendapatkan informasi secara langsung dari pihak bank bahwa dana mereka aman karena telah dijamin melalui lembaga penjamin simpanan, sehingga dapat menepis kekhawatiran pihak nasabah penyimpan dana pada bank.

Lembaga tersebut nantinya diharapkan dapat menjadi lembaga yang memberikan jaminan terhadap dana nasabah penyimpan dan diharapkan dapat lebih baik dari yang selama ini pernah ada dalam hal menjamin dana pihak ketiga, baik dari segi kepastian hukum tentang dana simpanan nasabah pada suatu bank, maupun sisi pelayanan, dan secara hukum.

Lembaga tersebut dipayungi oleh peraturan perundang-undangan yang 
memadai, sehingga kelahiran dan keberadaannya dapat benar - benar dirasakan sangat bermanfaat bagi masyarakat secara umum dan nasabah penyimpan secara khusus.

Perlindungan hukum bagi rakyat Indonesia Philipus M. Hadjon mengatakan bahwa ada dua macam perlindungan hukum bagi rakyat, yaitu perlindungan hukum yang preventif bertujuan untuk mencegah terjadinya sengketa dan perlindungan hukum represif yang bertujuan untuk menyelesaikan sengketa. ${ }^{18}$

Pada hakekatnya perlindungan hukum itu berkaitan bagaimana hukum memberikan keadilan yaitu memberikan atau mengatur hak-hak terhadap subyek hukum, selain itu juga berkaitan bagaimana hukum memberikan keadilan terhadap subyek hukum yang dilanggar haknya.

Di depan dijelaskan bahwa hubungan antara nasabah penyimpan dengan bank berdasarkan hubungan kontraktual, dimana dalam hubungan kontraktual ini hak-hak nasabah penyimpan lahir dari kontrak/perjanjian penyimpanan dana yang dibuat oleh bank dengan nasabah penyimpan sendiri. Selain itu hak-hak nasabah penyimpan juga diatur/diberikan oleh KUHPerdata maupun ketentuan hukum perbankan.

Hanya saja perjanjian penyimpanan dana dalam praktek isinya ditentukan oleh pihak bank, seperti berapa besarnya bunga simpanan, dan biasanya perjanjian penyimpanan dana merupakan perjanjian standar/baku yang biasanya terdapat ketentuan yang lebih menguntungkan pihak bank.

Selain itu atas tagihan simpanan pada bank tersebut nasabah penyimpan tidak mungkin memperjanjikan jaminan/agunan atas pengembalian tagihan simpanannya

\footnotetext{
${ }^{18}$ Sulistyandary, Perlindungan Hukum nasabah Korban pembobolan rekening (Bagian II), http://www.google.com, senin 1 february 2010, hal 1.
}

seperti halnya dalam perjanjian kredit. Sehingga jika hal ini dihubungkan dengan perlindungan hukum terhadap nasabah penyimpan.

Maka dalam hubungan kontraktual ini bisa dikatakan perlindungan hukum terhadap nasabah penyimpan sangat kurang dibandingkan perlindungan hukum atas hak/tagihan bank terhadap nasabah peminjam dalam perjanjian kredit. Jika terjadi pelanggaran hak nasabah penyimpan oleh bank dalam hubungan kontraktual.

Seharusnya perlindungan hukum diberikan oleh perjanjian penyimpanan dana itu sendiri karena perjanjian adalah undang-undang bagi mereka yang membuatnya, sedang KUHPerdata memberikan hak-hak kepada nasabah penyimpan sebagaimana yang disebutkan antara lain dalam Pasal 1267 KUHPerdata.

Yang mengatakan bahwa pihak terhadap siapa perikatan itu tidak dipenuhi, maka dapat memilih apakah ia, jika hal itu masih dapat dilakukan, akan memaksa pihak yang lain untuk memenuhi perjanjian, ataukah ia akan menuntut pembatalan perjanjian, disertai penggantian biaya, rugi dan bunga.

Maka jika terjadi kasus dimana ketika nasabah penyimpan tabungan akan menarik tabungannya beserta bunga sesuai yang diperjanjikan melalui alat eletronik (misalnya ATM) dan jika ternyata tabungannya berkurang/habis karena pembobolan oleh pihak lain yang jelas bukan karena kesalahan nasabah penyimpan (biasanya bank perlu bukti untuk hal ini).

Maka nasabah penyimpan memperoleh perlindungan hukum dari Pasal 1267 KUHPerdata, artinya nasabah dapat menggunakan hak-haknya sesuai dengan Pasal tersebut. Dalam hubungan kontraktual ini sebenarnya nasabah penyimpan mendapatkan perlindungan hukum dalam bidang perdata. 
Dalam perlindungan hukum perdata pada prinsipnya warga negara boleh mengatur sendiri menurut pandangannya hubungan satu sama lain (asas otonomi). Asas otonomi warga negara ini antara lain ialah kebebasan membuat kontrak (isi suatu persetujuan, pada dasarnya bebas dari campur tangan pembuat undangundang).

Otonomi para warga negara dalam hukum privat itu mencakup juga, bahwa kepada para warga negara itu diserahkan, apakah mereka mempertahankan atau tidak mempertahankan haknya itu. Mengingat hubungan nasabah penyimpan dengan bank merupakan hubungan yang diatur dalam hukum perbankan dan jika dilihat pada ruang lingkup hukum perbankan termasuk dalam kategori campuran hukum privat dan hukum publik.

Maka jika dari sisi hukum perdata hubungan antara nasabah penyimpan dengan bank, nasabah penyimpan kurang terlindungi, maka seharusnya perlindungan hukum terhadap nasabah penyimpan dapat diberikan melalui hukum publik atas hakhaknya terhadap bank.

Dalam hubungan non kontraktual, hakhak nasabah penyimpan terhadap bank muncul karena adanya hukum tertulis (UU Perbankan, UU BI dan peraturan pelaksanaan) dan hukum tidak tertulis, hubungan non kontraktual yang diatur dalam UU Perbankan dan peraturan pelaksananya yaitu :

1. Hubungan kepercayaan;

2. Hubungan kerahasiaan;

3. Hubungan menjamin simpanan nasabah penyimpan;

4. Hubungan kepedulian terhadap resiko nasabah;

5. Hubungan kepedulian terhadap pengaduan nasabah.

Hal itu dapat diuraikan sebagai berikut : Hubungan Kepercayaan

Hubungan ini tersimpul dari Pasal 1 angka 2, Pasal 1 angka 5 dan Pasal 3 UU
Perbankan, bahwa bank adalah badan usaha yang menghimpun dana dari masyarakat dalam bentuk simpanan dan menyalurkannya kepada masyarakat dalam bentuk kredit dan/atau bentuk-bentuk lainnya dalam rangka meningkatkan taraf hidup rakyat banyak.

Fungsi utama perbankan Indonesia adalah sebagai penghimpun dan penyalur dana masyarakat. Simpanan adalah dana yang dipercayakan oleh masyarakat kepada bank berdasarkan perjanjian penyimpanan dana dalam bentuk Giro, Deposito, Tabungan dan/atau bentuk lainnya yang dipersamakan dengan itu.

Dari beberapa pasal tersebut dapat diketahui bahwa bank adalah lembaga perantara/intermediasi (intermediary institution), dimana bank menghimpun dana dari masyarakat dalam bentuk simpanan, disini muncul hubungan hukum antara bank (debitur) dengan nasabah penyimpan (kreditur), nasabah penyimpan mempercayakan dana simpanannya kepada bank untuk dikelolah, untuk itu nasabah penyimpan berhak atas pengembalian simpanan dengan bunga.

Kemudian oleh bank dana simpanan tersebut disalurkan kepada nasabah peminjam, disini muncul juga hubungan hukum antara bank (kreditur) dengan nasabah peminjam (debitur), bank menyalurkan dana simpanan kepada nasabah peminjam dalam bentuk kredit.

Artinya bank juga mempercayakan dana itu kepada nasabah peminjam untuk dikelola, dan untuk itu bank berhak atas pengembalian dana yang dipinjamkan dengan bunganya. Dengan demikian dari beberapa pasal tersebut tersimpul adanya suatu asas/prinsip kepercayaan (fiduciary) dalam pengaturan perbankan Indonesia.

Oleh karena lembaga intermediasi adalah merupakan kegiatan utama bank, maka keuntungan bank yang utama juga adalah selisih bunga pinjaman dengan bunga simpanan. Mengingat dari kegiatan 
utama bank tersebut pada akhirnya bertujuan untuk menunjang pelaksanaan pembangunan nasional dalam rangka meningkatkan pemerataan, pertumbuhan ekonomi, dan stabilitas nasional kearah peningkatan kesejahteraan rakyat banyak.

Maka kepada nasabah penyimpan yang telah mempercayakan dananya kepada bank perlu mendapatkan perlindungan hukum yang memadai. Perlindungan hukum tersebut diatur dalam Pasal 8 tentang pemberian kredit, Pasal 16 tentang perizinan dan 29 tentang pembinaan dan pengawasan perbankan, artinya bank harus menjalankan kegiatan usaha dengan prinsip kehati-hatian.

Kemudian pembinaan dan pengawasan bank oleh Bank Indonesia sebenarnya merupakan suatu ketentuan dalam UU Perbankan yang pada akhirnya juga bertujuan untuk memberikan perlindungan terhadap bank yang bersangkutan dan nasabah penyimpan, dan jika terjadi pelanggaran kewajiban bank yang berkaitan dengan ketentuan yang mengatur prinsip kehati-hatian, pembinaan dan pengawasan ini.

Bank dikenai sanksi administratif sesuai dengan Pasal 52 UU Perbankan yang berupa teguran tertulis, dan pelanggaran itu dapat diperhitungkan dengan komponen tingkat kesehatan bank, bahkan bank dapat diberikan sanksi pencabutan izin usaha, dan dengan adanya ketentuan Pasal 49 ayat (2) huruf b UU Perbankan maka Direksi dari bank yang bersangkutan dapat diadukan oleh nasabah sebagai telah melaksanakan tindak pidana dan dijatuhi sanksi pidana.

\section{F. PENUTUP}

\section{Kesimpulan}

1. Bank Indonesia sebagai pemegang otoritas perbankan Indonesia dalam upaya memenuhi standar yang berlaku dalam bidang perbankan telah memprioritaskan program- program terkait terhadap perlindungan nasabah, penanganan pengaduan nasabah, dan termasuk penanganan pembentukan lembaga mediasi perbankan yang independen. Perlunya manajemen resiko ini sebagai bentuk yang ada kaitannya dengan kepercayaan masyarakat terhadap dunia perbankan, sehingga perlu menghindari potensi terjadinya suatu peristiwa (events) yang dapat menimbulkan kerugian bank.

2. Dalam praktik perbankan berlaku ketentuan bahwa nasabah yang akan menyimpan dananya disuatu bank dilakukan bukan dengan cumacuma. Nasabah berhak untuk menerima bunga atas dana yang disimpan pada bank tersebut. Secara yuridis, hubungan antara bank dengan nasabah penyimpan adalah berkaitan satu sama lain, disatu pihak nasabah menginginkan dana yang dimilikinya aman dengan dititipkan pada bank, disisi yang lain bank mengharapkan masyarakat menitipkan dananya pada bank yang bersangkutan dengan harapan dana yang terkumpul nantinya dapat disalurkan melalui kredit dan bank memperoleh imbalan bunga dari pihak debitur.

\section{Saran}

1. Pihak pemerintah agar lebih memperhatikan kegiatan dari bankbank terutama bagi Bank Indonesia sebagai pembina dan pengawas terhadap kegiatan perbankan agar dalam hal ini pihak bank lebih bertanggungjawab dan memperhatikan apa yang menjadi hak-hak dari pihak nasabah dan apabila bank-bank pelaksana melalaikan kewajiban dan tanggungjawab maka perlu ada 
sanksi yang tegas terhadap bank tersebut.

2. Mengingat perlindungan hukum terhadap nasabah penyimpan dana masih sangat kurang dan sering tidak melakukan kewajibannya sehingga nasabah merasakan banyak kerugian. Untuk itu kepada pihak bank agar lebih lagi meningkatkan perlindungan hukum termasuk hak dan kewajiban nasabah bank bisa lebih terlindungi.

\section{DAFTAR PUSTAKA}

Djumhana, Muhamad., Hukum Perbankan di Indonesia, PT Citra Aditya Bakti, Bandung, 1996.

----------------., Hukum Perbankan di Indonesia, PT Citra Aditya Bakti, Bandung, 2006.

Gazali, Djono S dan Rachmadi Usman, Hukum Perbankan, Sinar Grafika, Jakarta, 2010.

Santoso Az., Lukaman., Hak dan Kewajiban Nasabah Bank, Pustaka Yustisia, Yogyakarta, 2011.

Simorangkir, O.P., Pengatar Lembaga Keuangan Bank dan Non Bank, Ghalia Indonesia, 2004.

Sembiring, Sentosa., Hukum Perbankan, Mandar Maju, Bandung, 2000.

------., Hukum Perbankan, Mandar Maju, Bandung, 2008.

Untung, H. Budi., Kredit Perbankan di Indonesia, Andi, Yogyakarta, 2005.

Widjanarto, Hukum dan Ketentuan Perbankan di Indonesia, Pustaka Utama Grafiti, 2005.

\section{SUMBER - SUMBER LAIN \\ Hadad, Muliaman D., Perlindungan dan Pemberdayaan Nasabah Bank dalam Arsitektur Perbankan Indonesia, http://www.google.com. \\ Sulistyandary, Perlindungan Hukum Nasabah Korban Pembobolan Rekening}

(Bagian II), http://www.google.com, Senin 1 February 2010.

Undang - Undang Nomor 5 Tahun 1999 Tentang Perlindungan Konsumen.

Undang - Undang Nomor 10 Tahun 1998 Tentang Perbankan. 